\title{
Principal causes and challenges for reducing product returns: applying FMEA in a case study
}

\author{
Principais causas e desafios para a redução de retorno de \\ produtos: aplicação da FMEA em um estudo de caso
}

\author{
Bruna Caffaro Boccaletti ${ }^{1}$, Luiz Carlos Brasil de Brito Mello ${ }^{2}$ (D), Isadora de Paula Bastos ${ }^{3}$ \\ ${ }^{1}$ Universidade Federal Fluminense - UFF, Niterói, RJ, Brasil. E-mail: brunacaffaro@id.uff.br \\ ${ }^{2}$ Universidade Federal Fluminense - UFF, Niterói, RJ, Brasil. E-mail: luiz.brasil@gmail.com \\ ${ }^{3}$ Universidade Federal Fluminense - UFF, Niterói, RJ, Brasil. E-mail: isadora.bastos@engenharia.uff.br
}

How to cite: Boccaletti, B. C., Mello, L. B. de B., Bastos, I. P. (2021). Principal causes and challenges for reducing product returns: applying FMEA in a case study. Gestão \& Produção, 28(2), e5115. https://doi.org/10.1590/1806-9649-2020v28e5115

\begin{abstract}
The current economy has demanded from organizations greater quality in their operations, which makes necessary to avoid non-compliance of processes that generate extra expenses, efforts and influence satisfaction of clients. This article aims to understand main causes of products returns from market in a cosmetics company. Based on literature review and application of a quality tool, FMEA (Failure Modes and Effects Analysis), in the case study, solutions and their effects on the organization are evaluated. After studies, new solutions and suggestions were proposed to reduce organization's post-sale reverse logistics.
\end{abstract}

Keywords: Reverse logistics; Market returns; Causes analysis; FMEA.

Resumo: A economia atual vem exigindo das organizações maior qualidade em suas operações, sendo necessário atentar a não conformidade dos processos que geram gastos e esforços extras e, influenciam a satisfação dos clientes. Diante disso, o presente artigo tem como objetivo compreender as principais causas de retornos de produtos do mercado em uma empresa de cosméticos. Munindo-se da literatura e da aplicação da ferramenta da qualidade FMEA (Análise de Modos de Falha e Efeitos) no estudo de caso, avaliam-se as soluções e seus efeitos na organização. Após estudos realizados foram propostas novas soluções e sugestões de estudos na redução da logística reversa pós-venda da organização.

Palavras-chave: Logística reversa; Retornos de mercado; Análise de causas; FMEA.

\section{Introduction}

Activities related to cosmetics can be understood as part of the Personal Hygiene, Perfumery and Cosmetics (HPPC in Portuguese) industry. Brazil is currently the world's fourth largest consumer products of this industry, which is also part of a larger group of consumer goods, usually referred to as Fast Moving Consumer Goods (FMCG). In this position, Brazil represents approximately $6.9 \%$ of world consumption of the HPPC industry. The net sales' taxes of HPPC industry increased from 21.3 to 47.5 billion reais

Received Sept. 15, 2018 - Accepted: Dec. 13, 2018

Financial support: None.

This is an Open Access article distributed under the terms of the Creative Commons Attribution License, which permits unrestricted use, distribution, and reproduction in any medium, provided the original work is properly cited. 
in 10 years since 2008, equivalent to an average deflated compound growth of close to $3.8 \%$ (ABIHPEC, 2018).

In face of these new demands and habits, in 2017 HPPC industry in Brazil had 2,718 companies regulated in ANVISA, with a greater concentration in Southeast region, with approximately 1,643 companies. Despite the number, there is a concentration of revenue in 15 large companies, which have net sales of taxes of more than 300 million reais, totaling $75 \%$ of the total collected by the whole sector (ABIHPEC, 2018).

Despite the growth scenario, Brazil recorded an $8 \%$ decrease in sales, net of sales tax, comparing 2016 to 2015 . Against this background, Brazil left the third position in these types of goods consumption and is now behind United States, China and Japan, occupying the fourth position (ABIHPEC, 2018).

To understand the cosmetic industry dynamics, it is also necessary understand the chain that makes up this business. Some factors are de-motivating in the importation process, such as taxes collection, products nationalization, transport operations risks and costs. However, there are cases in which these costs are advantageous, even by points as the added value because it is an internationally produced product. The trend has been to carry out the maximum of operations in national territory, apart from luxury products and those containing special formulas, mainly in the case of international companies.

Later in the chain, we go through the manufacturing process, in addition to products physical distribution. The strategic decision in these steps is to outsource both some products production and final products transportation. It is important in this case to understand particularities of each company and niches, since some products, like those of skin care, go to distribution centers of large pharmacies, while hair treatment lines are directed to small salons.

On the market context and the chain presented, companies have sought to guarantee their profitability through a strategic determination of a service level proposal appropriate to each consumer and to maintain the proposed quality, assuming strategic decisions previously mentioned, based on these factors. The organizational structures that are established must be aligned with these objectives in different areas such as product design and creation, negotiation and communication with customers and even after-sales management.

Redirecting the issue to the consumer goods industry, it is understood that in a context in which product does not meet what was expected by consumers, intermediary or end consumer. It is also expected a post consumer action that will demonstrate a commitment to quality proposed to client and seek their satisfaction.

Based on these principles, the general objective of the present paper is to understand main causes and decisions of organizations that demand previously explained flow of post-sale reverse logistics, understanding these dynamics within the organizational context. For this, a case study was carried out with the application of FMEA quality tool.

\subsection{Organizational strategy}

Global changes have led to increased international competition. These changes bring new competitive areas and accentuate some existing ones with new factors such as image, innovation and relationships. In addition to short-term profit, the main focus is directed at meeting a variety of social, environmental and governmental interests that 
guarantee profitability over time, together with sustainability and organization perpetuity (Hernández, 2010).

For Mintzberg \& Quinn (2001), strategy can be understood as a plan that unites goals, policies and actions of an organization in a coherent way. Thus, when the strategy is concise, it allows company or institution to order and allocate its resources in a more optimized way, understanding its internal capabilities, as well as external changes also for contingency plans.

Other authors, such as Jauch \& Glueck (1980), approach strategy as the way to achieve company's basic objectives. Similar to the aforementioned authors, this concept is related to the whole, analogous to a plan of unification and integration to relate what is sought in relation to challenges found in the organization's environment. In addition, Porter (2005) states that the competitive strategy goal is to promote design of offensive and defensive actions to position the organization in a way that is desired, having resources to defend itself and face competitive forces such as bargaining power of customers, bargaining of suppliers, threat of new entrants, threat of substitutes products, and competitive rivalry. These components form Porter's Five Forces framework, designed by Michael Porter.

\subsection{Organizacional culture}

Studies about culture, organizational values and organizational climate have gained importance in understanding organizational behavior (Agum, 2014). The way that employees and management deal with these components impacts dynamics of the organization adopted strategy.

Some moments in history have impacted interest in organizational culture study and its influence in strategies implementation adopted by organizations. One of the main moments occurred during the 1980s, when the Japanese economy was successful and the US economy, on the contrary, was in relative decline. In this scenario, interest arose to understand reasons why this success was appearing in the Japanese organizations (Coleta \& Naves, 2003; Ferreira \& Assmar, 2008; Pinto \& Vergara, 1998; Schein, 1992; Silva \& Zanelli, 2004). Ouchi (1981) considers that the main factor of the Japanese organization's prominence is the workers involvement with the philosophy, way of seeing the culture, and with companies' values. Similar involvement could not be explained because of cultural differences between the two countries. Thus, organizational culture arises to denote differences of companies within different scopes such as country, society, affecting key indicators such as efficiency and effectiveness.

Deepening the concepts about the theme, organizational culture can be understood as the set of basic beliefs and assumptions shared by members of an organization (Schein, 1992). This is one of the most commmon definitions for this concept, and there are also other scholars view of the theme, such as Hofstede et al. (2010), who affirm that the term organizational culture can be attributed to different collectivities. Therefore, culture will exist in its different dimensions as countries, regions, ethnic groups and, among these, organizations.

Delving into the organizational culture concept proposed by Schein (1992), it consists of a pattern of shared basic assumptions that prove effective in solving problems of external adaptation and internal integration. The assumptions are taught to new members of the organization and begin to integrate their organizational culture (Agum, 2014). 


\subsection{Supply chain}

According to Sheremetieff (2015), supply chain is understood from two views, the steps that come before the main manufacturer and those that come after it. The presence of several agents, interests and steps in the chain bring demand and opportunities for the supply chain management. Christopher (2011) considers that "management of upstream and downstream relationships with suppliers and customers aims to deliver superior value to customers at a lower cost to the supply chain as a whole."

Despite dissemination of the complementary concept to the previous one, Supply Chain Management (SCM), both in academia and in business environment, there is still considerable confusion as to its meaning (Cooper et al., 1997; Lambert 2008). For many years the term Supply Chain Management definition was not significantly different from the integrated logistics concept, but over time the term has gained new interpretations (Kent \& Flint, 1997). However, since its first citation in literature, it is possible to verify that there is no consensus regarding its meaning (Neder, 2015).

Lummus et al. (2001) consider that supply chain management involves all activities from purchase of raw materials to delivery of finished products to customer.

In both definitions, Supply Chain Management's main approach is cooperation and trust, that is, companies and suppliers work together to develop an efficient, effective, relevant and sustainable partnership. Thus, the proposal of a chain-wide management and the recognition of this partnership reflects in the philosophy that the whole can be greater than the sum of its parts (Christopher, 2011; Bowersox et al., 2014).

\subsection{Business logistics}

In addition to the cooperation objective among agents of the supply chain, its management aims to offer to customer the proposed level of service. In order to achieve this, a logistic network, with its unfolding in transportation, storage and materials, follows the logistic pyramid model (Figure 1) created by the COPPEAD Logistics Study Center (ILOS, 2016), the Institute of Logistics and Supply Chain (ILOS, 2016).

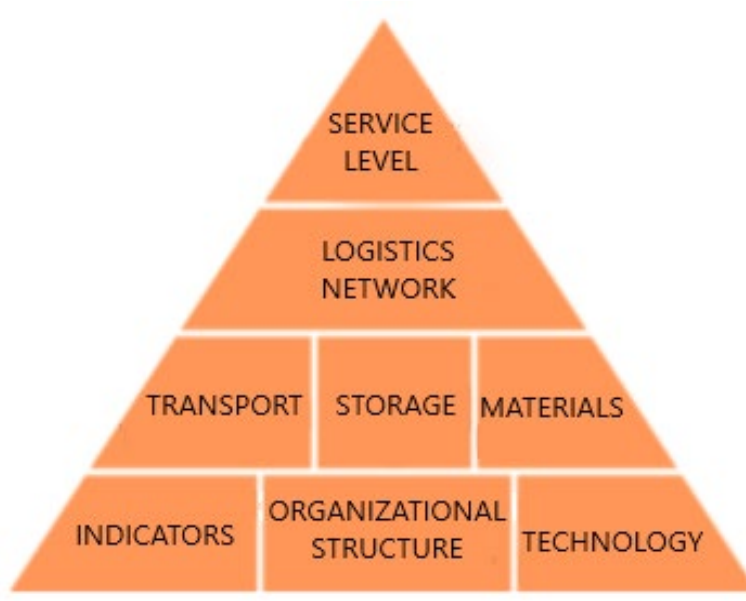

Figure 1. Logistics Pyramid. Source: Institute of Logistics and Supply Chain - ILOS (2016). 
The philosophy behind this model is that each component of this pyramid supports the above structure in order to provide to customers the desired level of service. Therefore, there is a strategy established by company, followed by a supply chain that must be aligned with objectives and, to support the latter, there is a management of the supply chain. All these components would dialogue and respond according to different organizational cultures.

According to Fawcett et al. (1997), there are more opportunities in investment in logistics to obtain competitive advantages in relation to elements currently present in the environment, such as supply chains composed of dependent relationships, changes in the channel's leadership, globalization, greater innovation among organizations, others.

Addressing the concept of the theme, Christopher (2011) defines that "logistics is essentially a planning orientation and a structure that aims to create a single plan for products flow and information through a business."

According to the Council of Supply Chain Management Professionals (CSCMP, 2005), business logistics can be conceptualized as the part of Supply Chain Management that plans, implements and controls direct and reverse flow, stock of goods, services and information from the beginning of flow to the point of consumption in terms of meeting customer needs (Hernández, 2010).

\subsection{Reverse logistics}

Reverse logistics can be understood as the process or area of logistics that plans, operates, and controls finished products flow and their information, from the point of consumption to the return to origin to recapture value or tailor their destination (Rogers \& Tibben-Lembke, 1999).

The term reverse logistics and the first studies of the subject began to appear in literature of the 70's and 80's, focusing on return of goods to be processed for recycling materials, currently referred to as post-consumer reverse logistics (Leite, 2005).

After first studies, other studies approached reverse logistics with a vision of strategic business management proposing strategies to formalize programs and to integrate reverse logistics in certain supply chains (Johnson, 1998; Srivastava, 2008).

It is possible to differentiate, at that moment, reverse logistics of post-sale and post-consumption, having these different objectives and ways of dealing with the flows. According to Leite (2005), after-sales reverse logistics can be defined as follows: Reverse aftermarket logistics is the specific area of reverse logistics that deals with planning, operation and control of the physical flow and corresponding logistics information of unused or underutilized after-sales goods that, for different reasons, return to different links in the direct distribution chain, which constitute a part of reverse channels through which these products flow. These products return for various reasons: commercial flaws, mistake at the time of issuing orders, warranty, manufacturing defects, operating or even for damages caused in transportation. 
Therefore, after-sales reverse logistics stands out due to product lack of use or little use. This logistics gained even more visibility and investment by companies in face of increase in service level demanded by consumers being a form of differentiation and customer loyalty (Chaves, 2005).

According to Leite (2003), in order to talk about post-consumer reverse logistics, it is necessary to talk about product life cycle, since the useful life of a product is understood as the time elapsed from its original production to the moment in which the first buyer discards it. Reinforcing the concept, one has a post-consumer good when the product useful life ends. This reverse logistics has gained potential to add value in face of increased environmental awareness (Ballou, 2001).

In order to better understand benefits for companies that perform reverse logistics activities, Sinnecker (2007) conducted a study of four large companies operating in Brazil to understand reasons that motivated them to start such activities. The main returns were: requirements of supply chain intermediate customers, environmental reasons, market demand and external environment. These factors highlight the different types of program selected for reverse logistics, such as: economic, legal, image, corporate citizenship or customer service (Leite, 2006).

\subsection{Logistic quality}

The concept of quality is discussed from different perspectives, in different activities, industrial, among other scopes. According to Silva (2002), four quality perspectives can be highlighted: quality for excellence, quality for compliance to specifications, quality for suitability for use and quality as value for price. Each perspective is related to decision making and what is meant by quality.

The first perspective is related to the definition given by Ferreira (1986), being related to "property, attribute or condition of things or people, capable of distinguishing them from each other and determining their nature." With respect to the second perspective compliance in meeting specifications, quality can be understood by obeying the standards established and adopted in relation to a product or service. The third perspective, suitability for use, refers to the ability to satisfy customer demands of usability, meeting their needs. In this vision, product or service would serve client in a reliable, safe and timely manner (Paladini, 2007).

The fourth perspective encompasses main points of the last three, since it brings quality as a relation between value for customer and the price for which service or product is offered. Quality comes to be understood as service, excellence and usability of what is offered with a compatible price and with an acceptable variation (Broh, 1974).

Several quality experts have proposed their definitions for the term quality, with these different trends revolving around previously cited perspectives.

\subsection{FMEA quality tool}

Quality Tools are techniques created and adapted in different environments with objective of identifying, measuring and proposing solutions for nonconformities and tracing possible improvements in the studied environment. 
Failure Mode and Effect Analysis (FMEA) is an engineering technique used to define, identify, and eliminate known or potential failures of systems, projects, processes, and / or services, before they can impact the client (Laurenti et al., 2012; Recchia, 2016).

FMEA methodology has two stages, first one being qualitative, when failure modes, effects and causes are identified, and the second quantitative, where failures are scored in relation to their risk, seeking to ensure that they are mitigated and or controlled (Puente et al., 2002; Recchia, 2016). After the definition of system to be analyzed, failure modes, effects and causes, the risk assessment phase begins, which is based on three criteria to calculate the Risk Priority Number (RPN). The three criteria are explained by Recchia (2016) as follows:

Severity (S): is an evaluation of the potential failure mode effects severity, severity can be scored on a scale of 1 to 10 in FMEA standard model, where one (1) is equal to a minimum severity and ten (10) at maximum severity.

Occurrence (O): is the probability of an event listed in severity occurrs, the probability of occurrence can be listed on a scale of 1 to 10 in the standard FMEA model, where one (1) is equal to the minimum and ten (10) maximum.

Detection (D): it is an evaluation of what the probability that the control of the process is structured to perceive and to avoid that the fault occurs in a scale of 01 to 10 .

In view of the previously presented flow and according to Ebrahimipour et al. (2010), the generic process to implement FMEA methodology is to initially describe the product or process; then define functions and describe faults; subsequently define effects and their causes; describe current control methods; calculate risks, and finally determine actions and evaluate results obtained.

Therefore, it can be said that this methodology is basis for achieving quality and, as Moura (2000) affirms, at present, there is a great commitment of companies to present continuous improvement for processes and products, becoming this important tool due to its preventive character and elimination of potential failures to avoid errors that may lead to customer disintegration (Duim, 2016).

It is important to highlight two main types of FMEA, which one is process-oriented, and other for design, both of which can be used in evolution of product design or in its process (Palady, 1997). Design Failure Modes and Effects Analysis (DFMEA) identifies possible failures that may occur with the product while in its project specification. This type of FMEA aims to avoid failures by providing information that helps in programs planning consisting of efficient and complete projects by developing a list of potential failures according to consequences to its clients, establishing project improvements priorization and development trials, and consider project requirements evaluation and alternative solutions (Moura, 2000).

Process Failure Mode and Effects Analysis (PFMEA) considers possible failures in process planning and execution (Duim, 2016). For Silva et al. (2008), the existing changes between project specifications and product are the factors that are analyzed to avoid failures in the product execution, that is, in the execution of the process.

When starting FMEA, a table with necessary information for the study is used. Table 1 presents columns to fill in possible flaws and their respective data as: their effects, their causes, explanations and their indexes of risk prioritization (AGQ, 2006). 
Table 1. FMEA Fill Model.

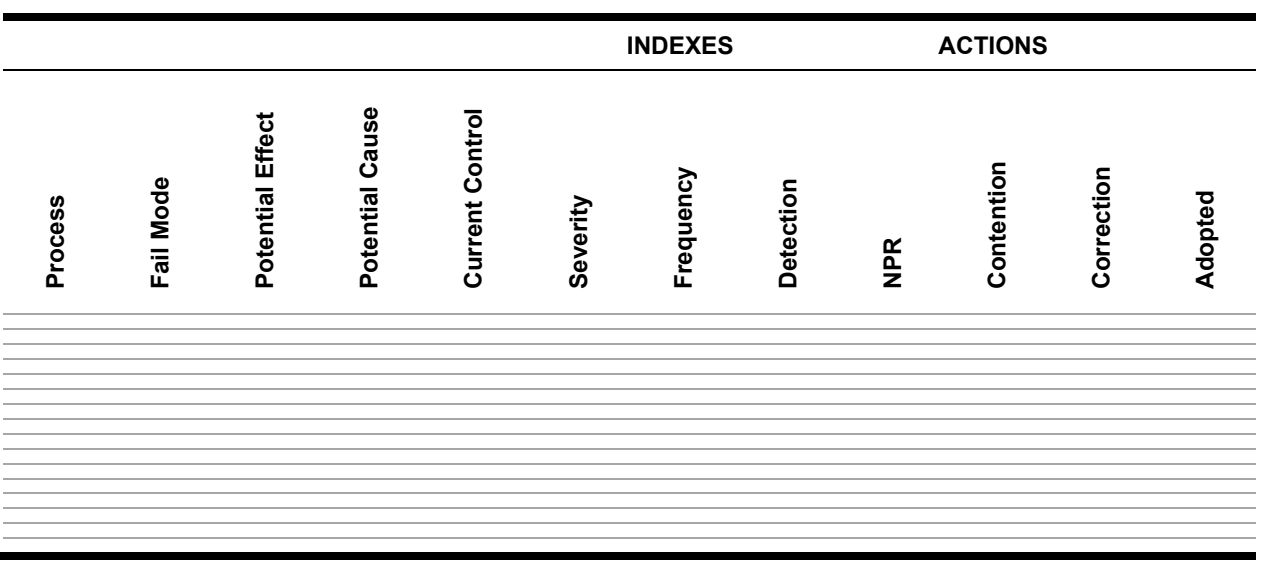

Source: AGQ (2006).

In the first column, "Process", one must fill in what is being analyzed, that is, a succinct definition about the process, product or operation being evaluated. Then, in the "Failure Mode" column, you should analyze possible flaws that this process / product can produce, that is, to present possible reasons why it can not perform its function successfully. The "Potential effect" column, should be filled through a study of possible effects that these failures can cause, being for product, people or company itself, depending on what one prefers to analyze (Duim, 2016).

In "Potential Cause" column, causes that give rise to failures are identified. From this column and "Current Control" column, which deals with process controls, it is possible to perform the score of causes with respect to their severity, occurrence and detection, meaning, the Risk Priority Number (RPN). The prioritization method for determining the cause risk depends exclusively on the team choice, to the one that is most appropriate for the study.

After prioritization, it is necessary to identify corrective and containment actions suggested so that failure does not happen. Because these actions need to be monitored, someone responsible must be defined as well as a period for analysis to take place, if this person is able to obtain the considered results, thus having a column to record the action taken. After actions taken, indexes should be evaluated again, critically, to be able to determine new failure risk levels (Duim, 2016).

\section{Methodology}

The methodological choices complement each other in terms of the topic through bibliographic research, along with application in a case study and elaboration of action plans. For this, present research has an exploratory, descriptive and explanatory character. Exploratory, because studies related to reverse logistics were searched for in bibliography, but no publications related to HPPC branch were found as is proposed in the research; descriptive, because while searching for a global analysis of the system it was necessary to characterize and group from data sources; and explanatory; because explanations, evidence and possible actions are pursued for main causes of market returns in reverse logistics industry studied. 


\subsection{Bibliographic research}

As the research focus was generalization of strategic aspects of reverse logistics, it was necessary to deepen this theme both in national and international literature, to form the general theoretical basis, the main analysis according to the research problem and to elaborate the operational construct.

Firstly, the criterion followed for identification of research related to the topic of study involved search for papers that contained the word "reverse logistics" in order to find common concepts, characteristics and practices and to determine existing gaps to delimit the study, and determine the problem that was going to be developed.

Subsequently, more specific keywords related to the formulated research problem were used, among which are: "reverse logistics and management systems", "reverse logistics and performance measurement", "reverse logistics and decision-making methods with multi-criteria "," reverse logistics and business performance ", in addition to the topics related to" research methodology ". These researches were carried out in sources such as: Capes, UFRGS (thesis and dissertations), UFSC (thesis and dissertations), UFRJ (thesis and dissertations), UFMG (thesis and dissertations), among others and several others listed in the bibliography, besides the UFF library. These surveys were carried out in the period of March-June 2017.

Table 2 shows a summary of economy branches in which the largest number of studies on reverse logistics has appeared, involving some kind of reverse channel according to consulted bibliography.

From branches listed in Table 2, the motivation to understand reverse logistics strategies presented in personal hygiene scenario, perfumery and cosmetics industry, regarding decisions and causes related to reverse logistics of after-sales is presented. From a well-structured literature review, there is a more specific targeting for the case study.

Table 2. Economic branches with reverse logistics programs.

\begin{tabular}{lcc}
\hline \multicolumn{1}{c}{ Branches of economy } & Post-consumer channel & After-sales channel \\
\hline Food & $X$ & $X$ \\
\hline Automotive & $X$ & $X$ \\
\hline Editorial & & $X$ \\
\hline Home appliances & $X$ & \\
\hline Disposable packaging & $X$ & $X$ \\
\hline Pharmaceutical & & \\
\hline Hygiene & $X$ & $X$ \\
\hline Computing & $X$ & \\
\hline Construction material & $X$ & \\
\hline Metallurgical & $X$ & $X$ \\
\hline Paper & $X$ & $X$ \\
\hline Chemical & $X$ & \\
\hline Cell phone & & \\
\hline
\end{tabular}

Source: Hernández (2010).

\subsection{Case study}

The most appropriate methodology considered for the research proposed is the case study, which, as Yin (2001) explains, is the most appropriate method when basic questions are "how" or "why" type. 
The steps necessary to fulfill the objectives outlined in the field survey are: selection of companies for data collection; collection of data using specific techniques or instruments; analysis of data according to the research method used; data processing and validation of results. After the company is selected, the next topics are dedicated to approaching next phases defining data collection methods and analysis. In a simple way, methodology used for the present study can be consolidated in flow chart of Figure 2.

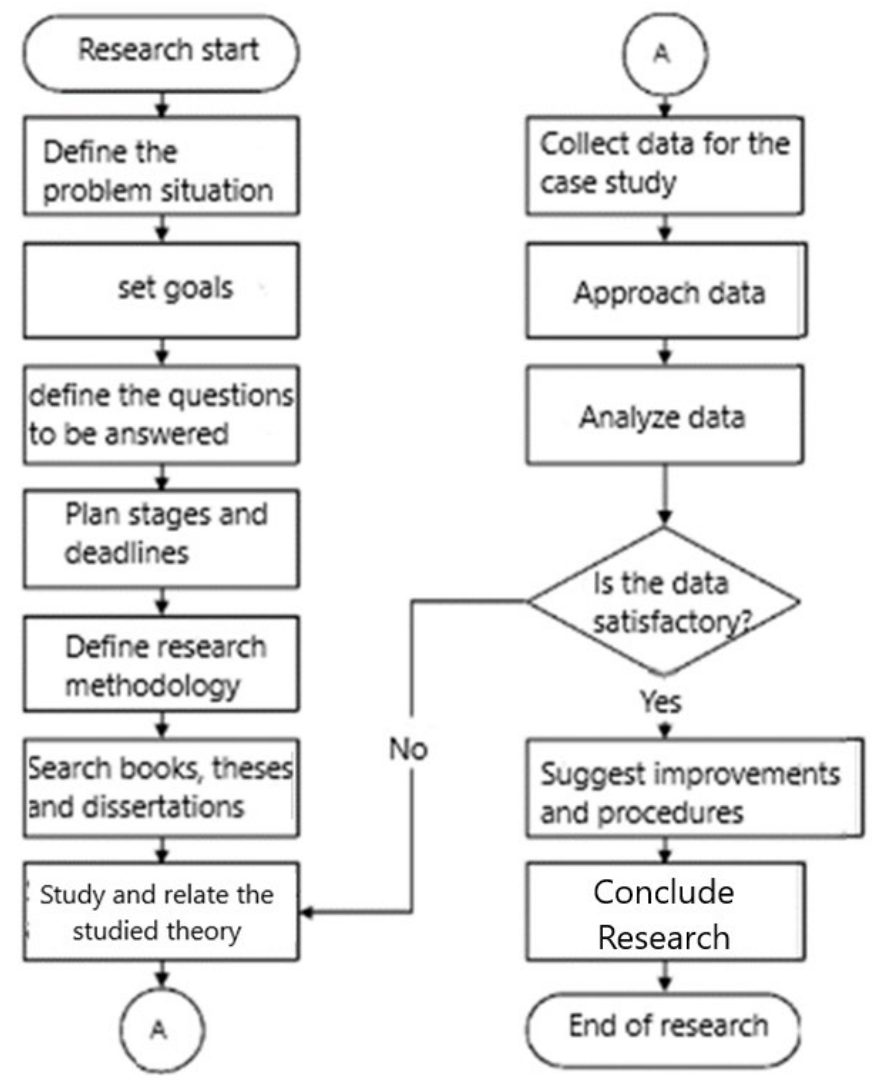

Figure 2. Research Methodology Flowchart. Source: Prepared by the authors (2018).

\subsection{Company studied description}

The company chosen for case study is considered to be the largest in world beauty industry, sector which is commonly referred to as Personal Hygiene, Perfumery and Cosmetics (PHPC). In the world scenario, the organization counts on about 89.000 employees, having activities distributed by 140 countries. With around 32 international brands, the organization had 25.8 billion euros in sales and 4.54 billion euros in operating profit in 2016.

In Brazil, where the sixth largest subsidiary of the group is located, the organization markets 25 different brands, with approximately 5.000 employees. In Brazil since 1959, the company's logistics network currently has three factories, a research and innovation center and four distribution centers in the country. Two factories, three distribution centers and the research and innovation center are located in the state of Rio de 
Janeiro, while the other plant is located in Sao Paulo and the fourth distribution center in Espírito Santo.

The logistics network described above makes up the organization supply chain in Brazil to reach the service level desired. The distribution service counts on outsourcing of transport service, with different companies for certain regions. The whole process from elaboration of bar codes, nationalization of some products, factory and distribution centers quality monitoring until product arrival in the client property presents risks of nonconformities, that directly impact on company's operations profitability. The present study analyzes the nonconformities found in company's products after sales.

\subsection{Supply chain and reverse logistics}

According to Sheremetieff (2015), supply chain is understood from two views, the steps that come before the main manufacturer and those that come after it. The presence of several agents, interests and steps in the chain bring a demand and opportunities for supply chain management. Christopher (2011) considers that "management of upstream and downstream relationships with suppliers and customers aims to deliver superior value to customer at a lower cost to the supply chain as a whole."

Reverse logistics can be understood as the process or area of logistics that plans, operates, and controls finished products flow and their information, from point of consumption to return to origin for the purpose of recapturing value or tailoring their destination (Rogers \& Tibben-Lembke, 1999).

The company's product flow begins in two ways: some products are imported, and the nationalization and labeling processes carried out at the responsible third-party company. While others, in greater quantity, are produced in factories in Brazil. Both flows forward products to distribution centers, where, with different order profiles, product goes to customers of different sizes.

In the distribution centers, products are separated into positions for unit picking, bases for closed boxes and pallet storage locations. The different orders are processed in different ways from this availability, whose control and resupply are controlled by the stock sector.

In this scenario, distribution centers quality team is responsible for guaranteeing quality in different product stages in the logistics flow, being these: what comes from factory and importer, commonly referred to as inbound; what is in the different positions previously presented, available for delivery to customers; what is in the unit picking boxes, which undergo check; and finally, what is to be dispatched. This control follows a pre-established pattern of nonconformity, which is used as basis for training of distribution center operators as well as of lecturers of outsourced carriers.

The final stages of the products expected flow consist of product shipping and delivery to customer, which is performed by different outsourced carriers. The control with these service providers is through training and indicator controls, revisiting the need to scale other carriers.

Although the physical nonconformities that reach the customer are in materials flow, it is also necessary to understand nonconformities whose causes are in product developments and in information flow. The company sales process in question occurs in two ways, the first being the order entered by the company's commercial sector and the second by the customer. Both are billed by the area responsible for customer service operations, Customer Care. 
In terms of information flow, it is up to the Commercial and Customer Care to establish an effective and dynamic communication with the purpose of guaranteeing updating of information such as address, updating of product codes for entry, modifications of the product's warehouse, among others.

Seeking to standardize reasons why customers return their products or why these can not be delivered, an online tool was created to record occurrences. The scheme of Table 3 represents in a simplified way, flow of materials and information with their respective failure modes found since June 2017.

Table 3. Processes and Proposed Failure Modes.

\begin{tabular}{|c|c|c|}
\hline & TACTICS & FAILURE MODES \\
\hline & Import Operation & Non-conforming product requirements \\
\hline & Factory Production & Non-conforming product requirements \\
\hline & Factory Preparation & $\begin{array}{l}\text { Breakdowns, quantity divergences, } \\
\text { volumes/inverted items }\end{array}$ \\
\hline \multirow{2}{*}{ 嵒照 } & $\begin{array}{l}\text { Supply and processes - } \\
\text { CD }\end{array}$ & $\begin{array}{l}\text { Divergence of quantity, volumes/items reversed, } \\
\text { non-conforming validity }\end{array}$ \\
\hline & Order preparation - CD & $\begin{array}{l}\text { Failures, divergence of quantity, volumes / items } \\
\text { reversed, order requirements }\end{array}$ \\
\hline & Order incoming & $\begin{array}{l}\text { Failures, divergence of quantity, volumes / items } \\
\text { reversed, incoming divergence, tax divergence / } \\
\text { collection, claim }\end{array}$ \\
\hline & Order receipt & $\begin{array}{l}\text { Divergence of information in the customer's } \\
\text { system, divergence in receipt }\end{array}$ \\
\hline$\stackrel{\theta}{\operatorname{r} C o}$ & $\begin{array}{l}\text { Typing the request - Sales } \\
\text { Force }\end{array}$ & Non-conforming order, inconsonant price \\
\hline 㫛 & $\begin{array}{l}\text { Typing the request - } \\
\text { EDI/Billing }\end{array}$ & Non-conforming order, inconsonant price \\
\hline$\because=$ & Order verification/customer & $\begin{array}{l}\text { Tax divergence / charged, product not registered, } \\
\text { order canceled }\end{array}$ \\
\hline
\end{tabular}

Source: Prepared by the authors (2018).

Table 3 failures were defined through analysis and evaluation of causes and failures. So it is possible to involve connoisseurs of the processes studied to start application of FMEA within the company.

\subsection{FMEA application}

Failure Mode and Effect Analysis (FMEA) is an engineering technique used to define, identify, and eliminate known or potential failures of systems, projects, processes, and / or services, before they impact client (Laurenti et al., 2012; Recchia, 2016).

FMEA methodology has two stages, first one being qualitative, when failure modes, effects and causes are identified, and the second quantitative, where failures are scored in relation to their risk, seeking to ensure that they are mitigated and/or controlled (Puente et al., 2002; Recchia, 2016). After definition of system to be analyzed, failure modes, effects and causes, the risk assessment phase begins, which 
is based on three criteria for calculation of Risk Priority Number (RPN). Given this, the proposed classification model was constructed in Table 4.

Table 4. Adapted criteria table.

\begin{tabular}{|c|c|c|c|}
\hline Evaluation & $\begin{array}{l}\text { Detection (cause control } \\
\text { capability and / or failure } \\
\text { mode) }\end{array}$ & $\begin{array}{l}\text { Occurrence } \\
\text { (of cause) }\end{array}$ & Severity (of effect) \\
\hline 1 & Error-proof device & 0 & Accomplished issuance \\
\hline 2 & $\begin{array}{c}\text { Multiple automatic checking } \\
\text { in } 100 \% \text { of cases (various } \\
\text { process steps) }\end{array}$ & $0.1 \%$ to $5 \%$ & First reissuance \\
\hline 3 & $\begin{array}{c}\text { Automatic verification in } \\
100 \% \text { of cases }\end{array}$ & $5.1 \%$ to $10 \%$ & Second reissuance \\
\hline 4 & $\begin{array}{c}\text { Multiple manual checking in } \\
100 \% \text { of cases (various } \\
\text { process steps) }\end{array}$ & $10.1 \%$ to $15 \%$ & Credit node \\
\hline 5 & $\begin{array}{c}\text { Manual verification in } 100 \% \\
\text { of cases }\end{array}$ & $15.1 \%$ to $20 \%$ & Replenishment \\
\hline 6 & $\begin{array}{l}\text { Multiple sample verification } \\
\text { (various process steps) }\end{array}$ & $20.1 \%$ to $25 \%$ & Partial regress - void invoice \\
\hline 7 & $\begin{array}{l}\text { Single step sampling } \\
\text { verification }\end{array}$ & $25.1 \%$ to $30 \%$ & Partial regress $<20 \mathrm{~K}$ \\
\hline 8 & $\begin{array}{c}\text { Random verification based } \\
\text { on previous guindance } \\
\text { (training) }\end{array}$ & $30.1 \%$ to $50 \%$ & Partial regress $>20 \mathrm{~K}$ \\
\hline 9 & $\begin{array}{l}\text { Random verification without } \\
\text { previous guindance }\end{array}$ & $50.1 \%$ to $70 \%$ & Integral regress $<100 \mathrm{~K}$ \\
\hline 10 & No verification & $70.1 \%$ to $100 \%$ & Integral regress > $100 \mathrm{~K}$ \\
\hline
\end{tabular}

Source: Prepared by the authors (2018).

Analyzing the criteria, detection (first column) was thus defined from processes analysis and through discussions with process experts and their directors, who can better define capacity to control causes. Already the criterion occurrence is defined by number of times that a given cause happened on the total number of occurrences of all causes. This rule is dynamic, aiming to maintain values average similar to other rules average, since when increasing the number of possible causes, the percentages become very low and frequency has little relevance.

Finally, the criterion related to severity is very specific to the company, since these are solutions found for deliveries that, for some reason, occur unexpectedly and require some resolution. Since they are the ones with greatest financial and operational impact and cause greater dissatisfaction, FMEA tool will initially treat cases of partial return (return of part of origin invoice), full return (return of all invoice goods of origin) and replacement (sending a product to replace what was claimed by the customer).

The criteria presented here were defined through meetings and discussions about what would be effectively understood by process stakeholders, so it was essential to involve them in preparation of Table 5. For this case study, construction of the table lasted approximately one month, counting on adjustments, modifications and seeking quality professionals support inside the organization. 
Having the criteria ready to be used in FMEA, it is essential to understand data that will be inserted and its accuracy. Input data in this case study are all return orders created inside organization, in other words, any release of the company so that the product returns to company's distribution center and, consequently, that customer receives credit for this return, except in some circumstances.

With respect to the analyzing process of these orders, it happens weekly, ensuring that the cycle is closed at end of the month. Each return order has an occurrence history evaluated by the account responsible tracker, whose reason is later evaluated by company's reverse logistics area, especially when little or no information is granted. It is at this stage, therefore, that one has the greatest challenge in the reliability of information presented about an occurrence. For such, the studied company has an online platform to record these events.

Following construction of necessary bases and the occurrences case-by-case analysis, there is a division of these occurrences into their respective processes, in order to better target transactions and to identify gaps in processes and their controls. Processes and their subdivisions were also defined in FMEA construction, dialoguing with areas involved and providing experiences obtained in analyses. From this constant effort and using the established criteria, calculation of the FMEA Risk Priority Numbers can be performed.

In view of previously mentioned criteria and analysis performed from June to August 2017, Table 5 presents the highest RPNs:

Table 5. Calculated RPN (June to August).

\begin{tabular}{|c|c|c|c|c|c|c|c|c|}
\hline 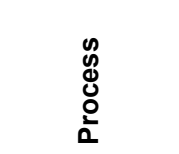 & $\begin{array}{l}\frac{0}{0} \\
\frac{0}{\Sigma} \\
\frac{\bar{\pi}}{\mathbb{N}}\end{array}$ & 志 & 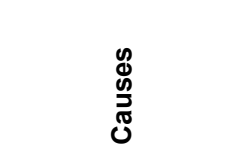 & 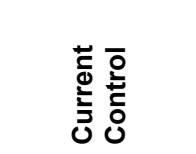 & $\frac{\grave{o}}{\frac{0}{\alpha}}$ & 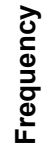 & 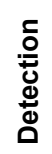 & $\frac{\mathscr{n}}{\underline{\alpha}}$ \\
\hline $\begin{array}{c}\text { Request } \\
\text { Typing - } \\
\text { Sales Force }\end{array}$ & $\begin{array}{l}\text { non } \\
\text { conforming } \\
\text { request }\end{array}$ & $\begin{array}{l}\text { full return < } \\
100 \mathrm{k}\end{array}$ & $\begin{array}{c}\text { without request/ } \\
\text { unsolicited } \\
\text { quantity(SF) }\end{array}$ & no verification & 8 & 10 & 10 & 800 \\
\hline $\begin{array}{c}\text { Order } \\
\text { Issuance }\end{array}$ & $\begin{array}{l}\text { volume } \\
\text { failure/ } \\
\text { items }\end{array}$ & $\begin{array}{l}\text { full return > } \\
100 \mathrm{k}\end{array}$ & failure - delivery & $\begin{array}{c}\text { one-step } \\
\text { sampling } \\
\text { verification }\end{array}$ & 10 & 9 & 7 & 630 \\
\hline $\begin{array}{c}\text { Order } \\
\text { Issuance }\end{array}$ & $\begin{array}{l}\text { divergence } \\
\text { of quantity }\end{array}$ & $\begin{array}{l}\text { full return > } \\
100 \mathrm{k}\end{array}$ & $\begin{array}{c}\text { divergence of } \\
\text { quantity - delivery }\end{array}$ & $\begin{array}{c}\text { one-step } \\
\text { sampling } \\
\text { verification }\end{array}$ & 10 & 9 & 7 & 630 \\
\hline $\begin{array}{l}\text { Order Typing } \\
\text { - Sales } \\
\text { Force }\end{array}$ & $\begin{array}{l}\text { non } \\
\text { conforming } \\
\text { request }\end{array}$ & $\begin{array}{c}\text { partial return } \\
>20 k\end{array}$ & $\begin{array}{c}\text { without request/ } \\
\text { unsolicited } \\
\text { quantity(SF) }\end{array}$ & no verification & 6 & 10 & 10 & 600 \\
\hline $\begin{array}{c}\text { Order } \\
\text { Issuance }\end{array}$ & $\begin{array}{l}\text { volume } \\
\text { failure/ } \\
\text { items }\end{array}$ & $\begin{array}{l}\text { full return < } \\
100 \mathrm{k}\end{array}$ & failure - delivery & $\begin{array}{c}\text { one-step } \\
\text { sampling } \\
\text { verification }\end{array}$ & 8 & 9 & 7 & 504 \\
\hline $\begin{array}{c}\text { Order } \\
\text { Issuance }\end{array}$ & $\begin{array}{l}\text { divergence } \\
\text { of quantity }\end{array}$ & $\begin{array}{l}\text { full return < } \\
100 \mathrm{k}\end{array}$ & $\begin{array}{c}\text { divergence of } \\
\text { quantity - delivery }\end{array}$ & $\begin{array}{c}\text { one-step } \\
\text { sampling } \\
\text { verification }\end{array}$ & 8 & 9 & 7 & 504 \\
\hline $\begin{array}{c}\text { Order } \\
\text { Preparation }\end{array}$ & $\begin{array}{l}\text { volume } \\
\text { failure/ } \\
\text { items }\end{array}$ & $\begin{array}{l}\text { full return < } \\
100 \mathrm{k}\end{array}$ & $\begin{array}{c}\text { failure - } \\
\text { preparation (DCs) }\end{array}$ & $\begin{array}{c}\text { multiple } \\
\text { sample } \\
\text { verification } \\
\text { (various } \\
\text { stages of the } \\
\text { process) }\end{array}$ & 8 & 9 & 7 & 504 \\
\hline
\end{tabular}


Table 5. Continued...

\begin{tabular}{|c|c|c|c|c|c|c|c|c|}
\hline $\begin{array}{l}\text { đo } \\
\text { d } \\
0 \\
0\end{array}$ & $\frac{\frac{0}{0}}{\sum}$ & 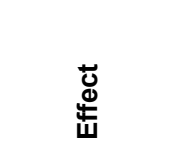 & 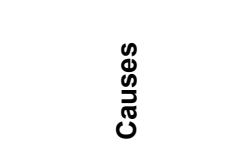 & 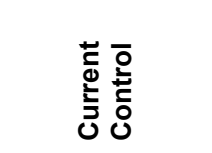 & $\frac{\grave{o}}{\bar{\alpha}}$ & $\begin{array}{l}\text { dे } \\
\frac{0}{0} \\
\frac{0}{0} \\
\frac{d}{4}\end{array}$ & 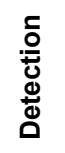 & $\begin{array}{l}\frac{n}{\frac{N}{0}} \\
\frac{\alpha}{2}\end{array}$ \\
\hline $\begin{array}{c}\text { Order } \\
\text { Preparation }\end{array}$ & $\begin{array}{l}\text { volumes/ } \\
\text { inverted } \\
\text { items }\end{array}$ & $\begin{array}{l}\text { full return > } \\
100 \mathrm{k}\end{array}$ & $\begin{array}{c}\text { reversal - } \\
\text { preparation/ } \\
\text { picking (DCs) }\end{array}$ & $\begin{array}{c}\text { manual } \\
\text { verification in } \\
100 \% \text { of cases }\end{array}$ & 10 & 10 & 5 & 500 \\
\hline $\begin{array}{c}\text { Factory } \\
\text { Preparation }\end{array}$ & $\begin{array}{c}\text { volume } \\
\text { failure/ } \\
\text { items }\end{array}$ & $\begin{array}{c}\text { full return < } \\
100 \mathrm{k}\end{array}$ & $\begin{array}{c}\text { Coloring } \\
\text { fragility/Promo }\end{array}$ & $\begin{array}{l}\text { multiple } \\
\text { sample } \\
\text { verification } \\
\text { (various } \\
\text { stages of the } \\
\text { process) }\end{array}$ & 8 & 10 & 6 & 480 \\
\hline $\begin{array}{c}\text { Order / } \\
\text { customer } \\
\text { verification }\end{array}$ & $\begin{array}{l}\text { canceled } \\
\text { order }\end{array}$ & $\begin{array}{l}\text { full return < } \\
100 \mathrm{k}\end{array}$ & order cancellation & no verification & 8 & 6 & 10 & 480 \\
\hline $\begin{array}{c}\text { Order } \\
\text { Preparation }\end{array}$ & $\begin{array}{l}\text { volumes/ } \\
\text { inverted } \\
\text { items }\end{array}$ & $\begin{array}{l}\text { full return < } \\
100 \mathrm{k}\end{array}$ & $\begin{array}{c}\text { reversal - } \\
\text { preparation/ } \\
\text { picking (DCs) }\end{array}$ & $\begin{array}{c}\text { manual } \\
\text { verification in } \\
100 \% \text { of cases }\end{array}$ & 8 & 10 & 5 & 400 \\
\hline $\begin{array}{l}\text { Order Typing } \\
\text { - Sales } \\
\text { Force }\end{array}$ & $\begin{array}{l}\text { non } \\
\text { conforming } \\
\text { request }\end{array}$ & $\begin{array}{l}\text { partial return } \\
\quad<20 \mathrm{k}\end{array}$ & $\begin{array}{c}\text { without request/ } \\
\text { unsolicited } \\
\text { quantity(SF) }\end{array}$ & no verification & 4 & 10 & 10 & 400 \\
\hline $\begin{array}{c}\text { Order } \\
\text { Issuance }\end{array}$ & $\begin{array}{l}\text { divergence } \\
\text { of quantity }\end{array}$ & $\begin{array}{l}\text { partial return } \\
>20 \mathrm{k}\end{array}$ & $\begin{array}{c}\text { divergence of } \\
\text { quantity - delivery }\end{array}$ & $\begin{array}{c}\text { one-step } \\
\text { sampling } \\
\text { verification }\end{array}$ & 6 & 9 & 7 & 378 \\
\hline $\begin{array}{l}\text { Order } \\
\text { Receipt }\end{array}$ & $\begin{array}{c}\text { divergence } \\
\text { of } \\
\text { information } \\
\text { in the } \\
\text { customer's } \\
\text { system }\end{array}$ & $\begin{array}{l}\text { full return }< \\
100 \mathrm{k}\end{array}$ & $\begin{array}{l}\text { divergence in the } \\
\text { system/ customer } \\
\text { conference } \\
\text { (general) }\end{array}$ & $\begin{array}{l}\text { random } \\
\text { checking } \\
\text { based on } \\
\text { previous } \\
\text { guidance } \\
\text { (training) }\end{array}$ & 8 & 5 & 8 & 320 \\
\hline $\begin{array}{c}\text { Order } \\
\text { Issuance }\end{array}$ & loss & Full return & force majeure & no verification & 10 & 3 & 10 & 300 \\
\hline $\begin{array}{c}\text { Order } \\
\text { Preparation }\end{array}$ & $\begin{array}{l}\text { volumes/ } \\
\text { inverted } \\
\text { items }\end{array}$ & $\begin{array}{l}\text { partial return } \\
>20 \mathrm{k}\end{array}$ & $\begin{array}{l}\text { preparation/ } \\
\text { picking (DCs) }\end{array}$ & $\begin{array}{c}\text { manual } \\
\text { verification in } \\
100 \% \text { of cases }\end{array}$ & 6 & 10 & 5 & 300 \\
\hline $\begin{array}{l}\text { Order Typing } \\
\text { - Sales } \\
\text { Force }\end{array}$ & $\begin{array}{l}\text { non } \\
\text { conforming } \\
\text { request }\end{array}$ & $\begin{array}{l}\text { full return }> \\
100 \mathrm{k}\end{array}$ & $\begin{array}{l}\text { other (typing } \\
\text { request) (SF) }\end{array}$ & no verification & 10 & 3 & 10 & 300 \\
\hline $\begin{array}{l}\text { Order Typing } \\
\text { - Sales } \\
\text { Force }\end{array}$ & $\begin{array}{l}\text { non } \\
\text { conforming } \\
\text { request }\end{array}$ & $\begin{array}{c}\text { full return }< \\
100 \mathrm{k}\end{array}$ & duplicate request & $\begin{array}{l}\text { random } \\
\text { checking } \\
\text { based on } \\
\text { previous } \\
\text { guidance } \\
\text { (training) }\end{array}$ & 8 & 4 & 8 & 256 \\
\hline $\begin{array}{c}\text { Order } \\
\text { Issuance }\end{array}$ & $\begin{array}{l}\text { volume } \\
\text { failure/ } \\
\text { items }\end{array}$ & $\begin{array}{l}\text { partial return } \\
\quad<20 k\end{array}$ & failure - delivery & $\begin{array}{c}\text { one-step } \\
\text { sampling } \\
\text { verification }\end{array}$ & 4 & 9 & 7 & 252 \\
\hline $\begin{array}{l}\text { Order } \\
\text { Issuance }\end{array}$ & $\begin{array}{l}\text { divergence } \\
\text { of quantity }\end{array}$ & $\begin{array}{l}\text { partial return } \\
\quad<20 \mathrm{k}\end{array}$ & $\begin{array}{l}\text { divergence of } \\
\text { quantity - delivery }\end{array}$ & $\begin{array}{c}\text { one-step } \\
\text { sampling } \\
\text { verification }\end{array}$ & 4 & 9 & 7 & 252 \\
\hline $\begin{array}{c}\text { Order } \\
\text { Preparation }\end{array}$ & $\begin{array}{l}\text { volume } \\
\text { failure/ } \\
\text { items }\end{array}$ & $\begin{array}{l}\text { partial return } \\
\quad<20 k\end{array}$ & $\begin{array}{c}\text { failure - } \\
\text { preparation (DCs) }\end{array}$ & $\begin{array}{c}\text { multiple } \\
\text { sample } \\
\text { verification } \\
\text { (various stages } \\
\text { of the process) }\end{array}$ & 4 & 9 & 7 & 252 \\
\hline
\end{tabular}

Source: Prepared by the authors (2018). 
The cases highlighted above are those with RPN greater than twice the average of all RPNs and are therefore the ones that most impact return results and demand action. This is the rule initially used, later, with resolution of some faults, other cases will become highlighted and be solved. Since failure modes and their causes are repeated due to different effects caused, a summary (Table 6 ) of the previously is presented, to evaluate decisions related to each one organization's processes.

Table 6. Higher offenders returning (June to August).

\begin{tabular}{|c|c|c|c|}
\hline Process & Fail Mode & Causes & Current Control \\
\hline Factory preparation & $\begin{array}{l}\text { volume failure/ } \\
\text { items }\end{array}$ & Coloring fragility/Promo & $\begin{array}{l}\text { multiple sample } \\
\text { verification (various } \\
\text { stages of the } \\
\text { process) }\end{array}$ \\
\hline Order preparation & $\begin{array}{l}\text { volume failure/ } \\
\text { items }\end{array}$ & failure - preparation (DCs) & $\begin{array}{l}\text { multiple sample } \\
\text { verification (various } \\
\text { stages of the } \\
\text { process) }\end{array}$ \\
\hline Order preparation & $\begin{array}{l}\text { volumes/ } \\
\text { inverted items }\end{array}$ & $\begin{array}{l}\text { reversal - preparation/ } \\
\text { picking (DCs) }\end{array}$ & $\begin{array}{l}\text { manual verification in } \\
100 \% \text { of cases }\end{array}$ \\
\hline Delivery of the order & loss & force majeure & no verification \\
\hline Delivery of the order & $\begin{array}{l}\text { volume failure/ } \\
\text { items }\end{array}$ & failure - delivery & $\begin{array}{l}\text { one-step sampling } \\
\text { verification }\end{array}$ \\
\hline Delivery of the order & $\begin{array}{l}\text { divergence of } \\
\text { quantity }\end{array}$ & $\begin{array}{l}\text { divergence of quantity - } \\
\text { delivery }\end{array}$ & $\begin{array}{l}\text { one-step sampling } \\
\text { verification }\end{array}$ \\
\hline Receiving the request & $\begin{array}{l}\text { divergence of } \\
\text { information in } \\
\text { the customer's } \\
\text { system }\end{array}$ & $\begin{array}{l}\text { divergence in the system/ } \\
\text { customer conference } \\
\text { (general) }\end{array}$ & $\begin{array}{l}\text { random checking } \\
\text { based on previous } \\
\text { guidance (training) }\end{array}$ \\
\hline $\begin{array}{l}\text { Typing the request - } \\
\text { Sales Force }\end{array}$ & $\begin{array}{l}\text { non } \\
\text { conforming } \\
\text { request }\end{array}$ & $\begin{array}{l}\text { without request/ } \\
\text { unsolicited quantity(SF) }\end{array}$ & no verification \\
\hline $\begin{array}{l}\text { Typing the request - } \\
\text { Sales Force }\end{array}$ & $\begin{array}{l}\text { non } \\
\text { conforming } \\
\text { request }\end{array}$ & $\begin{array}{l}\text { other (typing request) } \\
\text { (SF) }\end{array}$ & no verification \\
\hline $\begin{array}{l}\text { Typing the request - } \\
\text { Sales Force }\end{array}$ & $\begin{array}{l}\text { non } \\
\text { conforming } \\
\text { request }\end{array}$ & duplicate request (SF) & $\begin{array}{l}\text { random checking } \\
\text { based on previous } \\
\text { guidance (training) }\end{array}$ \\
\hline $\begin{array}{l}\text { Order / customer } \\
\text { verification }\end{array}$ & canceled order & order cancellation & no verification \\
\hline
\end{tabular}

Source: Prepared by the authors (2018).

\section{Analysis of results}

The FMEA proposal is that from suggested actions implementations, there are changes in the previously calculated Risk Priority Numbers (RPN). Therefore, presentation of each action will be done together with evolution of Risk Priority Number until October, evaluating actions effectiveness, but also presenting context in which they were taken. Initially, it presents a table with RPNs evolution for causes of greatest impact previously presented, emphasizing that results are accumulated. Therefore, Table 7 shows new notes, which refer to organization behavior from June to October 2017. 
Table 8 presents all proposed actions, whether performed or not, for each failure mode and its causes. It should be emphasized that suggested actions are capable of analysis and involvement of responsible areas and are therefore limited to immediate onset.

Table 7. Evolution of RPNs from June to October.

\begin{tabular}{|c|c|c|c|c|c|c|c|}
\hline 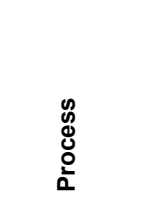 & $\begin{array}{l}\frac{0}{0} \\
\frac{0}{\Sigma} \\
\overline{\bar{T}} \\
\text { ய }\end{array}$ & 志 & 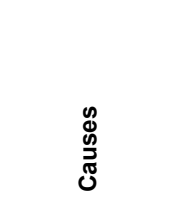 & 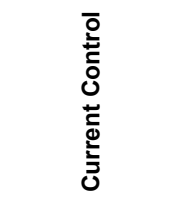 & $\begin{array}{l}\text { O্তি } \\
\text { \& } \\
\dot{5} \\
\frac{5}{3} \\
\frac{5}{2} \\
\frac{\alpha}{2} \\
z\end{array}$ & 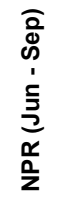 & 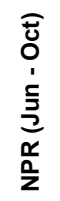 \\
\hline $\begin{array}{c}\text { Request } \\
\text { Typing - } \\
\text { Sales Force }\end{array}$ & $\begin{array}{l}\text { non } \\
\text { conforming } \\
\text { request }\end{array}$ & $\begin{array}{l}\text { full return } \\
<100 k\end{array}$ & $\begin{array}{c}\text { without } \\
\text { request/ } \\
\text { unsolicited } \\
\text { quantity(SF) }\end{array}$ & no verification & 800 & 720 & 800 \\
\hline $\begin{array}{c}\text { Order } \\
\text { Issuance }\end{array}$ & $\begin{array}{l}\text { volume } \\
\text { failure/ } \\
\text { items }\end{array}$ & $\begin{array}{l}\text { full return } \\
>100 k\end{array}$ & $\begin{array}{l}\text { failure - } \\
\text { delivery }\end{array}$ & $\begin{array}{c}\text { one-step } \\
\text { sampling } \\
\text { verification }\end{array}$ & 630 & 630 & 630 \\
\hline $\begin{array}{c}\text { Order } \\
\text { Issuance }\end{array}$ & $\begin{array}{l}\text { divergence } \\
\text { of quantity }\end{array}$ & $\begin{array}{l}\text { full return } \\
>100 k\end{array}$ & $\begin{array}{l}\text { divergence of } \\
\text { quantity - } \\
\text { delivery }\end{array}$ & $\begin{array}{c}\text { one-step } \\
\text { sampling } \\
\text { verification }\end{array}$ & 630 & 630 & 700 \\
\hline $\begin{array}{c}\text { Order } \\
\text { Typing - } \\
\text { Sales Force }\end{array}$ & $\begin{array}{l}\text { non } \\
\text { conforming } \\
\text { request }\end{array}$ & $\begin{array}{l}\text { partial } \\
\text { return > } \\
20 \mathrm{k}\end{array}$ & $\begin{array}{c}\text { without } \\
\text { request/ } \\
\text { unsolicited } \\
\text { quantity(SF) }\end{array}$ & no verification & 600 & 600 & 600 \\
\hline $\begin{array}{c}\text { Order } \\
\text { Issuance }\end{array}$ & $\begin{array}{l}\text { volume } \\
\text { failure/ } \\
\text { items }\end{array}$ & $\begin{array}{l}\text { full return } \\
<100 k\end{array}$ & $\begin{array}{l}\text { failure - } \\
\text { delivery }\end{array}$ & $\begin{array}{c}\text { one-step } \\
\text { sampling } \\
\text { verification }\end{array}$ & 504 & 504 & 504 \\
\hline $\begin{array}{l}\text { Order } \\
\text { Issuance }\end{array}$ & $\begin{array}{l}\text { divergence } \\
\text { of quantity }\end{array}$ & $\begin{array}{l}\text { full return } \\
<100 k\end{array}$ & $\begin{array}{l}\text { divergence of } \\
\text { quantity - } \\
\text { delivery }\end{array}$ & $\begin{array}{c}\text { one-step } \\
\text { sampling } \\
\text { verification }\end{array}$ & 504 & 504 & 560 \\
\hline $\begin{array}{c}\text { Order } \\
\text { Preparation }\end{array}$ & $\begin{array}{l}\text { volume } \\
\text { failure/ } \\
\text { items }\end{array}$ & $\begin{array}{l}\text { full return } \\
<100 k\end{array}$ & $\begin{array}{l}\text { failure - } \\
\text { preparation } \\
\text { (DCs) }\end{array}$ & $\begin{array}{c}\text { multiple sample } \\
\text { verification } \\
\text { (various stages } \\
\text { of the process) }\end{array}$ & 504 & 432 & 336 \\
\hline $\begin{array}{c}\text { Order } \\
\text { Preparation }\end{array}$ & $\begin{array}{l}\text { volumes/ } \\
\text { inverted } \\
\text { items }\end{array}$ & $\begin{array}{l}\text { full return } \\
>100 \mathrm{k}\end{array}$ & $\begin{array}{c}\text { reversal - } \\
\text { preparation/ } \\
\text { picking (DCs) }\end{array}$ & $\begin{array}{c}\text { manual } \\
\text { verification in } \\
100 \% \text { of cases }\end{array}$ & 500 & 240 & 270 \\
\hline $\begin{array}{c}\text { Factory } \\
\text { Preparation }\end{array}$ & $\begin{array}{l}\text { volume } \\
\text { failure/ } \\
\text { items }\end{array}$ & $\begin{array}{l}\text { full return } \\
<100 k\end{array}$ & $\begin{array}{c}\text { Coloring } \\
\text { fragility/Promo }\end{array}$ & $\begin{array}{l}\text { multiple sample } \\
\text { verification } \\
\text { (various stages } \\
\text { of the process) }\end{array}$ & 480 & 480 & 480 \\
\hline $\begin{array}{c}\text { Order / } \\
\text { customer } \\
\text { verification }\end{array}$ & $\begin{array}{l}\text { canceled } \\
\text { order }\end{array}$ & $\begin{array}{l}\text { full return } \\
<100 k\end{array}$ & $\begin{array}{c}\text { order } \\
\text { cancellation }\end{array}$ & no verification & 480 & 400 & 400 \\
\hline $\begin{array}{c}\text { Order } \\
\text { Preparation }\end{array}$ & $\begin{array}{l}\text { volumes/ } \\
\text { inverted } \\
\text { items }\end{array}$ & $\begin{array}{l}\text { full return } \\
<100 k\end{array}$ & $\begin{array}{c}\text { reversal - } \\
\text { preparation/ } \\
\text { picking (DCs) }\end{array}$ & $\begin{array}{c}\text { manual } \\
\text { verification in } \\
100 \% \text { of cases }\end{array}$ & 400 & 240 & 216 \\
\hline $\begin{array}{c}\text { Order } \\
\text { Typing - } \\
\text { Sales Force }\end{array}$ & $\begin{array}{l}\text { non } \\
\text { conforming } \\
\text { request }\end{array}$ & $\begin{array}{l}\text { partial } \\
\text { return < } \\
20 \mathrm{k}\end{array}$ & $\begin{array}{c}\text { without } \\
\text { request/ } \\
\text { unsolicited } \\
\text { quantity(SF) }\end{array}$ & no verification & 400 & 360 & 400 \\
\hline $\begin{array}{l}\text { Order } \\
\text { Issuance }\end{array}$ & $\begin{array}{l}\text { divergence } \\
\text { of quantity }\end{array}$ & $\begin{array}{c}\text { partial } \\
\text { return }> \\
20 \mathrm{k}\end{array}$ & $\begin{array}{l}\text { divergence of } \\
\text { quantity - } \\
\text { delivery }\end{array}$ & $\begin{array}{c}\text { one-step } \\
\text { sampling } \\
\text { verification }\end{array}$ & 378 & 378 & 420 \\
\hline
\end{tabular}


Table 7. Continued...

\begin{tabular}{|c|c|c|c|c|c|c|c|}
\hline 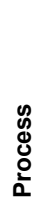 & $\begin{array}{l}\frac{0}{0} \\
\frac{\sum}{\Sigma} \\
\frac{\pi}{\pi}\end{array}$ & 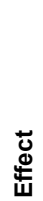 & 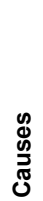 & 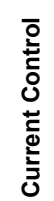 & $\begin{array}{l}\widehat{0} \\
\frac{3}{2} \\
1 \\
\frac{5}{5} \\
\frac{n}{2} \\
\frac{\alpha}{2}\end{array}$ & 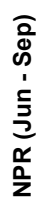 & $\begin{array}{l}\overline{\mathbf{U}} \\
0 \\
1 \\
\frac{5}{3} \\
\underline{2} \\
\frac{\alpha}{0} \\
\frac{0}{z}\end{array}$ \\
\hline
\end{tabular}

\begin{tabular}{|c|c|c|c|c|c|c|c|}
\hline $\begin{array}{l}\text { Order } \\
\text { Receipt }\end{array}$ & $\begin{array}{l}\text { divergence } \\
\text { of } \\
\text { information } \\
\text { in the } \\
\text { customer's } \\
\text { system }\end{array}$ & $\begin{array}{l}\text { full return } \\
<100 k\end{array}$ & $\begin{array}{l}\text { divergence in } \\
\text { the system/ } \\
\text { customer } \\
\text { conference } \\
\text { (general) }\end{array}$ & $\begin{array}{l}\text { random } \\
\text { checking based } \\
\text { on previous } \\
\text { guidance } \\
\text { (training) }\end{array}$ & 320 & 320 & 320 \\
\hline $\begin{array}{c}\text { Order } \\
\text { Issuance }\end{array}$ & loss & Full return & force majeure & no verification & 300 & 200 & 200 \\
\hline $\begin{array}{c}\text { Order } \\
\text { Preparation }\end{array}$ & $\begin{array}{l}\text { volumes/ } \\
\text { inverted } \\
\text { items }\end{array}$ & $\begin{array}{c}\text { partial } \\
\text { return }> \\
20 \mathrm{k}\end{array}$ & $\begin{array}{c}\text { preparation/ } \\
\text { picking (DCs) }\end{array}$ & $\begin{array}{c}\text { manual } \\
\text { verification in } \\
100 \% \text { of cases }\end{array}$ & 300 & 180 & 162 \\
\hline $\begin{array}{c}\text { Order } \\
\text { Typing - } \\
\text { Sales Force }\end{array}$ & $\begin{array}{l}\text { non } \\
\text { conforming } \\
\text { request }\end{array}$ & $\begin{array}{l}\text { full return } \\
>100 \mathrm{k}\end{array}$ & $\begin{array}{l}\text { other (typing } \\
\text { request) (SF) }\end{array}$ & no verification & 300 & 900 & 400 \\
\hline $\begin{array}{c}\text { Order } \\
\text { Typing - } \\
\text { Sales Force }\end{array}$ & $\begin{array}{l}\text { non } \\
\text { conforming } \\
\text { request }\end{array}$ & $\begin{array}{l}\text { full return } \\
<100 k\end{array}$ & $\begin{array}{l}\text { duplicate } \\
\text { request }\end{array}$ & $\begin{array}{c}\text { random } \\
\text { checking based } \\
\text { on previous } \\
\text { guidance } \\
\text { (training) }\end{array}$ & 256 & 64 & 256 \\
\hline $\begin{array}{c}\text { Order } \\
\text { Issuance }\end{array}$ & $\begin{array}{l}\text { volume } \\
\text { failure/ } \\
\text { items }\end{array}$ & $\begin{array}{c}\text { partial } \\
\text { return }< \\
20 \mathrm{k}\end{array}$ & $\begin{array}{l}\text { failure - } \\
\text { delivery }\end{array}$ & $\begin{array}{c}\text { one-step } \\
\text { sampling } \\
\text { verification }\end{array}$ & 252 & 84 & 252 \\
\hline $\begin{array}{l}\text { Order } \\
\text { Issuance }\end{array}$ & $\begin{array}{l}\text { divergence } \\
\text { of quantity }\end{array}$ & $\begin{array}{c}\text { partial } \\
\text { return }< \\
20 \mathrm{k}\end{array}$ & $\begin{array}{l}\text { divergence of } \\
\text { quantity - } \\
\text { delivery }\end{array}$ & $\begin{array}{l}\text { one-step } \\
\text { sampling } \\
\text { verification }\end{array}$ & 252 & 112 & 280 \\
\hline $\begin{array}{c}\text { Order } \\
\text { Preparation }\end{array}$ & $\begin{array}{l}\text { volume } \\
\text { failure/ } \\
\text { items }\end{array}$ & $\begin{array}{c}\text { partial } \\
\text { return }< \\
20 \mathrm{k}\end{array}$ & $\begin{array}{l}\text { failure - } \\
\text { preparation } \\
\text { (DCs) }\end{array}$ & $\begin{array}{l}\text { multiple sample } \\
\text { verification } \\
\text { (various stages } \\
\text { of the process) }\end{array}$ & 252 & 216 & 168 \\
\hline
\end{tabular}

Source: Prepared by the authors (2018).

Table 8. Monitoring of proposed actions.

\begin{tabular}{|c|c|c|c|c|c|c|}
\hline Process & Fail Mode & Causes & $\begin{array}{l}\text { Current } \\
\text { Control }\end{array}$ & Actions & $\begin{array}{c}\text { Classification } \\
\text { of Actions }\end{array}$ & Action Status \\
\hline $\begin{array}{l}\text { Factory } \\
\text { preparation }\end{array}$ & $\begin{array}{l}\text { volume } \\
\text { failure/ } \\
\text { items }\end{array}$ & $\begin{array}{l}\text { Coloring } \\
\text { fragility/Promo }\end{array}$ & $\begin{array}{l}\text { multiple } \\
\text { sample } \\
\text { verification } \\
\text { (various } \\
\text { stages of the } \\
\text { process) }\end{array}$ & $\begin{array}{l}\text { I. Strengthening } \\
\text { Promo Boxes }\end{array}$ & I. Correction & $\begin{array}{l}\text { I. Modifications } \\
\text { made in early } \\
2017 \text { - Next } \\
\text { modifications: } \\
2018\end{array}$ \\
\hline \multirow[b]{2}{*}{$\begin{array}{c}\text { Order } \\
\text { preparation }\end{array}$} & \multirow{2}{*}{$\begin{array}{l}\text { volume } \\
\text { failure/ } \\
\text { items }\end{array}$} & \multirow{2}{*}{$\begin{array}{l}\text { failure - } \\
\text { preparation } \\
\text { (DCs) }\end{array}$} & \multirow{2}{*}{$\begin{array}{l}\text { multiple } \\
\text { sample } \\
\text { verification } \\
\text { (various } \\
\text { stages of the } \\
\text { process) }\end{array}$} & $\begin{array}{l}\text { I. Task force on } \\
\text { dispatch }\end{array}$ & I. Contention & $\begin{array}{l}\text { I. In progress } \\
\text { since June } \\
2017\end{array}$ \\
\hline & & & & $\begin{array}{l}\text { II. } \\
\text { Strengthening } \\
\text { of the Master's } \\
\text { Box }\end{array}$ & II. Correction & $\begin{array}{l}\text { II. Tests in } \\
\text { progress, } \\
\text { implementation } \\
\text { in } 2018\end{array}$ \\
\hline \multirow{2}{*}{$\begin{array}{c}\text { Order } \\
\text { preparation }\end{array}$} & \multirow{2}{*}{$\begin{array}{l}\text { volumes/ } \\
\text { inverted } \\
\text { items }\end{array}$} & \multirow{2}{*}{$\begin{array}{c}\text { reversal - } \\
\text { preparation/ } \\
\text { picking (DCs) }\end{array}$} & \multirow{2}{*}{$\begin{array}{c}\text { manual } \\
\text { verification in } \\
100 \% \text { of cases }\end{array}$} & $\begin{array}{l}\text { I. Task force on } \\
\text { dispatch }\end{array}$ & I. Contention & $\begin{array}{l}\text { I. In progress } \\
\text { since June } \\
2017\end{array}$ \\
\hline & & & & $\begin{array}{c}\text { II. } \\
\text { Implementation }\end{array}$ & II. Correction & $\begin{array}{c}\text { II. End of } \\
\text { implementation }\end{array}$ \\
\hline
\end{tabular}


Table 8. Continued...

\begin{tabular}{|c|c|c|c|c|c|c|}
\hline Process & Fail Mode & Causes & $\begin{array}{l}\text { Current } \\
\text { Control }\end{array}$ & Actions & $\begin{array}{c}\text { Classification } \\
\text { of Actions }\end{array}$ & Action Status \\
\hline & & & & $\begin{array}{l}\text { of picking } \\
\text { methodology in } \\
\text { more lines }\end{array}$ & & $\begin{array}{l}\text { on all lines - } \\
\text { October } 2017\end{array}$ \\
\hline $\begin{array}{l}\text { Delivery of } \\
\text { the order }\end{array}$ & loss & force majeure & no verification & $\begin{array}{l}\text { I. Limiting exit } \\
\text { times }\end{array}$ & I. Contention & $\begin{array}{l}\text { I. Recurring } \\
\text { practice }\end{array}$ \\
\hline $\begin{array}{l}\text { Delivery of } \\
\text { the order }\end{array}$ & $\begin{array}{l}\text { volume } \\
\text { failure/ } \\
\text { items }\end{array}$ & $\begin{array}{l}\text { failure - } \\
\text { delivery }\end{array}$ & $\begin{array}{c}\text { one-step } \\
\text { sampling } \\
\text { verification }\end{array}$ & $\begin{array}{l}\text { I. Strengthening } \\
\text { of the Master's } \\
\text { Box }\end{array}$ & I. Correction & $\begin{array}{l}\text { I. Tests in } \\
\text { progress, } \\
\text { implementation } \\
\text { in } 2018\end{array}$ \\
\hline \multirow{2}{*}{$\begin{array}{l}\text { Delivery of } \\
\text { the order }\end{array}$} & \multirow{2}{*}{$\begin{array}{l}\text { divergence } \\
\text { of quantity }\end{array}$} & \multirow{2}{*}{$\begin{array}{l}\text { divergence of } \\
\text { quantity - } \\
\text { delivery }\end{array}$} & \multirow{2}{*}{$\begin{array}{c}\text { one-step } \\
\text { sampling } \\
\text { verification }\end{array}$} & $\begin{array}{l}\text { I. Survey of } \\
\text { gaps with the } \\
\text { shipping } \\
\text { company }\end{array}$ & I. Survey & $\begin{array}{l}\text { I. To be } \\
\text { performed }\end{array}$ \\
\hline & & & & $\begin{array}{l}\text { II. Charges for } \\
\text { cases of lack of } \\
\text { volume }\end{array}$ & II. Awareness & $\begin{array}{l}\text { II. Recurring } \\
\text { practice }\end{array}$ \\
\hline $\begin{array}{l}\text { Receiving } \\
\text { the request }\end{array}$ & $\begin{array}{l}\text { divergence } \\
\text { of } \\
\text { information } \\
\text { in the } \\
\text { customer's } \\
\text { system }\end{array}$ & $\begin{array}{l}\text { divergence in } \\
\text { the system/ } \\
\text { customer } \\
\text { conference } \\
\text { (general) }\end{array}$ & $\begin{array}{l}\text { random } \\
\text { checking } \\
\text { based on } \\
\text { previous } \\
\text { guidance } \\
\text { (training) }\end{array}$ & $\begin{array}{l}\text { No Mapped } \\
\text { Actions }\end{array}$ & - & - \\
\hline \multirow[b]{2}{*}{$\begin{array}{l}\text { Typing the } \\
\text { request - } \\
\text { Sales Force }\end{array}$} & \multirow[b]{2}{*}{$\begin{array}{l}\text { non } \\
\text { conforming } \\
\text { request }\end{array}$} & \multirow{2}{*}{$\begin{array}{c}\text { without } \\
\text { request/ } \\
\text { unsolicited } \\
\text { quantity(SF) }\end{array}$} & \multirow[b]{2}{*}{ no verification } & $\begin{array}{l}\text { 1. Changes to } \\
\text { the order form }\end{array}$ & I. Contention & $\begin{array}{c}\text { I. In progress } \\
\text { throughout the } \\
\text { year }\end{array}$ \\
\hline & & & & $\begin{array}{l}\text { II. Analysis and } \\
\text { Report of } \\
\text { nonconforming } \\
\text { request by } \\
\text { consultant }\end{array}$ & II. Awareness & $\begin{array}{c}\text { II. In progress } \\
\text { since October } \\
2017\end{array}$ \\
\hline \multirow[b]{2}{*}{$\begin{array}{l}\text { Typing the } \\
\text { request - } \\
\text { Sales Force }\end{array}$} & \multirow[b]{2}{*}{$\begin{array}{l}\text { non } \\
\text { conforming } \\
\text { request }\end{array}$} & \multirow[b]{2}{*}{$\begin{array}{l}\text { other (typing } \\
\text { request) (SF) }\end{array}$} & \multirow[b]{2}{*}{ no verification } & $\begin{array}{l}\text { 1. Changes to } \\
\text { the order form }\end{array}$ & I. Contention & $\begin{array}{c}\text { I. In progress } \\
\text { throughout the } \\
\text { year }\end{array}$ \\
\hline & & & & $\begin{array}{l}\text { II. Analysis and } \\
\text { Report of } \\
\text { nonconforming } \\
\text { request by } \\
\text { consultant }\end{array}$ & II. Awareness & $\begin{array}{c}\text { II. In progress } \\
\text { since October } \\
2017\end{array}$ \\
\hline \multirow{3}{*}{$\begin{array}{l}\text { Typing the } \\
\text { request - } \\
\text { Sales Force }\end{array}$} & \multirow{3}{*}{$\begin{array}{l}\text { non } \\
\text { conforming } \\
\text { request }\end{array}$} & \multirow{3}{*}{$\begin{array}{c}\text { duplicate } \\
\text { request (SF) }\end{array}$} & \multirow{3}{*}{$\begin{array}{l}\text { random } \\
\text { checking } \\
\text { based on } \\
\text { previous } \\
\text { guidance } \\
\text { (training) }\end{array}$} & $\begin{array}{l}\text { 1. Changes to } \\
\text { the order form }\end{array}$ & I. Contention & $\begin{array}{c}\text { I. In progress } \\
\text { throughout the } \\
\text { year }\end{array}$ \\
\hline & & & & $\begin{array}{l}\text { II. Analysis and } \\
\text { Report of } \\
\text { nonconforming } \\
\text { request by } \\
\text { consultant }\end{array}$ & II. Awareness & $\begin{array}{c}\text { II. In progress } \\
\text { since October } \\
2017\end{array}$ \\
\hline & & & & $\begin{array}{l}\text { III. Verification } \\
\text { of cases }\end{array}$ & III. Awareness & $\begin{array}{l}\text { III. In progress } \\
\text { since } \\
\text { September } \\
2017\end{array}$ \\
\hline \multirow[b]{2}{*}{$\begin{array}{c}\text { Order / } \\
\text { customer } \\
\text { verification }\end{array}$} & \multirow[b]{2}{*}{$\begin{array}{l}\text { canceled } \\
\text { order }\end{array}$} & \multirow[b]{2}{*}{$\begin{array}{c}\text { order } \\
\text { cancellation }\end{array}$} & \multirow[b]{2}{*}{ no verification } & $\begin{array}{l}\text { I. Process } \\
\text { definition }\end{array}$ & I. Correction & $\begin{array}{l}\text { I. Project for } \\
2018\end{array}$ \\
\hline & & & & $\begin{array}{l}\text { II. Analysis and } \\
\text { Report of } \\
\text { nonconforming } \\
\text { request by } \\
\text { consultant }\end{array}$ & II. Awareness & $\begin{array}{c}\text { II. In progress } \\
\text { since October } \\
2017\end{array}$ \\
\hline
\end{tabular}

Source: Prepared by the authors (2018). 


\section{Finals considerations}

This study main motivation was a more integrated understanding of causes of market returns. It was important to understand behaviors, limitations, challenges and, mainly, opportunities.

This paper consisted of a contextualization of contribution to a more macro view of challenges encountered in day-to-day business, besides a bibliographical research directed to seek dialogue between themes that complement each other for understanding the whole. Then, a parallel was drawn from the organizational strategy establishment to the use of a quality tool in order to achieve study's objective.

It is understood that decisions of the organization have a direct influence on results obtained. In macro factors, such as establishment of sales targets and response to market behavior to concentrate its purchases at the end of the month, or in micro factors such as areas that are overloaded, focus on certain outcomes and functions, and lack on focus on key points for customer satisfaction. In customer satisfaction, there is a demand for different areas to understand customer centricity company's idea, that is, customer satisfaction and customer service as a focus, in a context which cooperation and good relationship with customer will be necessary, so that decisions are profitable for the organization.

In the scenario presented, it is worth noting organization's movement to gain in service and costs by starting a strategy of change from within the organization, investing in a culture of cooperation and transparency. However, it is necessary to understand that this movement still faces limitations, mainly ramifications of objectives of areas and managements. Being that the objective of the company cooperation, but not having leaderships that may be more recent, interface or dialogues about goals that have been deployed to them, among other challenges, there is a difficulty in establishing a proposed culture. In an environment which collaboration is not effectively established, there is possibility of movements for greater collaboration, but there will always be moments in, which with the overload or with oppositions, attention will be paid only to what benefits goals and objectives themselves. In view of the above, it is necessary for leaders to understand their challenges and be able to reconcile goals and objectives, so that complementary and non-dichotomous activities and goals are deployed for employees. That way, also understanding the challenge due to organization studied size, different areas with different cultures and structures. It is understood as a necessity to effectively establish the culture of collaboration within the company to ensure quality throughout the chain. Despite the objectives achieved with the study, it is understood that there were limitations of time and other factors, which can be complemented by new studies and surveys inside and outside the organization studied.

\section{References}

Agum, F. S. (2014). Cultura organizacional e valores organizacionais: um estudo de caso (Master's thesis). Psychology Institute, Universidade Federal do Rio de Janeiro, Rio de Janeiro.

Associação Brasileira da Indústria de Higiene Pessoal, Perfumaria e Cosméticos - ABIHPEC. (2018). Panorama do setor higiene pessoal, perfumaria e cosméticos: resultados 2017. Retrieved in 2018, December 12, from https://abihpec.org.br/publicacao/panorama-dosetor-2018/ 
Associação Gaúcha para a Qualidade - AGQ. (2006). Curso FMEA: análise de modo e efeitos de falha em potencial (3. ed., 48 p.). Novo Hamburgo.

Ballou, H. R. (2001). Gerenciamento da cadeia de suprimentos: planejamento, organização e logística empresarial. Porto Alegre: Bookman.

Bowersox, D. J., Closs, D. J., Cooper, M. B., \& Bowersox, J. C. (2014). Gestão logística da cadeia de suprimentos (4. ed.). Porto Alegre: AMGH.

Broh, R. A. (1974). Managing quality for higher profits. New York: McGraw-Hill.

Chaves, G. L. D. (2005). Diagnóstico da logística reversa na cadeia de suprimentos de alimentos processados no oeste paranaense. In Anais do VIII Simpósio de Administração da Produção, Logística e Operações Internacionais (VIII SIMPOI). São Paulo: FGV.

Christopher, M. (2011). Logistics and supply chain management (4th ed.). Dorchester: Pearson Education/Henry Ling Ltd.

Coleta, M., \& Naves, E. (2003). Cultura e comprometimento organizacional em empresas hoteleiras. Revista de Administração Contemporânea, 7(spe), 205-222. http://dx.doi.org/10.1590/S1415-65552003000500011.

Cooper, M. C., Lambert, D. M., \& Pagh, J. D. (1997). Supply chain management: more than a new name for logistics. International Journal of Logistics Management, 8(1), 1-14. http://dx.doi.org/10.1108/09574099710805556.

Council of Supply Chain Management - CSCMP. (2005). Retrieved in 2017, June 12, from http://cscmp.org/

Duim, F. A. C. (2016). Estudo das causas do principal erro de produção da indústria automobilística brasileira em função dos recalls (Projeto final do curso). Production Engineering, Universidade Federal Fluminense.

Ebrahimipour, V., Rezaie, K., \& Shokravi, S. (2010). An ontology approach to support FMEA studies. Expert Systems with Applications, 37(1), 671-677. http://dx.doi.org/10.1016/j.eswa.2009.06.033.

Fawcett, S. E., Smith, S. R., \& Bixby Cooper, M. (1997). Strategic intent, measurement capability, and operational success: making the connection. International Journal of Physical Distribution \& Logistics Management, 27(7), 410-421. http://dx.doi.org/10.1108/09600039710188477.

Ferreira, A. B. H. (1986). Novo Dicionário da Língua Portuguesa. Rio de Janeiro: Nova Fronteira.

Ferreira, M. C., \& Assmar, E. M. L. (2008). Cultura organizacional. Medidas do comportamento organizacional: ferramentas de diagnóstico e de gestão. Porto Alegre: Artmed.

Hernández, C. T. (2010). Modelo de gerenciamento da logística reversa integrado às questões estratégicas das organizações (Doctorate's dissertation). Engineering College of Guaratingueta, Universidade Estadual Paulista, Guaratingueta.

Hofstede, G., Garibaldi de Hilal, A. V., Malvezzi, S., Tanure, B., \& Vinken, H. (2010). Comparing regional cultures within a country: lessons From Brazil. Journal of Cross-Cultural Psychology, 41(3), 336-352. http://dx.doi.org/10.1177/0022022109359696.

Instituto de Logística e Supply Chain - ILOS. (2016). Retrieved in 2017, June 13, from http://www.ilos.com.br

Jauch, L. R., \& Glueck, W. F. (1980). Business Policy and Strategic Management. New York: McGraw-Hill.

Johnson, S. D. (1998). Identification and selection of environmental performance indicators: application of the Balanced Scorecard Approach. Corporate Environmental Strategy, 5(4), 34-41. http://dx.doi.org/10.1016/S1066-7938(00)80079-2.

Kent, J. L., Jr., \& Flint, D. J. (1997). Perspectives on the evolution of logistics thought. Journal of Business Logistics, 18(2), 15-29. 
Lambert, D. M. (2008). Executive summary of supply chain management: processes, partnerships, performance (3rd ed.). Sarasota: Supply Chain Management.

Laurenti, R., Villari, B. D., \& Rozenfeld, D. H. (2012). Problemas e melhorias do método FMEA: uma revisão sistemática da literatura. $P \& D$ em Engenharia de Produção, 10(1), 59-70.

Leite, P. R. (2005). Logística reversa e competitividade empresarial. Revista Tecnologistica. Retrieved in 2017, May 25, from http://meusite.mackenzie.br/leitepr/Microsoft\%20Word\%20-\%20LR\%205\%20\%20LOGISTICA\%20REVERSA\%20E\%20A\%20COMPETITIVIDADE\%20EMPRESARIAL. pdf

Leite, P. R. (2006). Direcionadores (“DRIVERS") estratégicos em programas de logística reversa no Brasil. In Anais do IX Simpósio de Administração da Produção, Logística e Operações Internacionais (IX SIMPOI). São Paulo: FGV.

Leite, P. R. (2003). Logística reversa: meio ambiente e competitividade (1. ed.). São Paulo: Prentice Hall.

Lummus, R. R., Krumwiede, D. W., \& Vokurka, R. J. (2001). The relationship of logistics to supply chain management: developing a common industry definition. Industrial Management \& Data Systems, 101(8), 426-432. http://dx.doi.org/10.1108/02635570110406730.

Mintzberg, H., \& Quinn, J. B. (2001). O processo da estratégia (3. ed.). Porto Alegre: Bookman.

Moura, C. (2000). Análise de modo e efeitos de falha potencial (FMEA): manual de referência. São Paulo: IQA.

Neder, A. L. R. (2015). Melhores práticas na gestão da cadeia de suprimentos: um estudo de caso em uma rede de hospitais privados (Master's thesis). Institute COPPEAD of Administration, Universidade Federal do Rio de Janeiro, Rio de Janeiro.

Ouchi, W. G. (1981). Teoria Z: como as empresas podem enfrentar o desafio japonês. São Paulo: Nobel.

Paladini, E. P. (2007). Gestão da qualidade: teoria e prática (2. ed.). São Paulo: Atlas.

Palady, P. (1997). FMEA: análise dos modos de falha e efeitos: prevendo e prevenindo problemas antes que ocorram. São Paulo: IMAM.

Pinto, M., \& Vergara, S. (1998). Cultura e mudança organizacional: o caso TELERJ. RAC, 2 , 63-84.

Porter, M. E. (2005). Estratégia competitiva: técnicas para análise de indústrias e da concorrência (2. ed). Rio de Janeiro: Campus.

Puente, J., Pino, R., Priore, P., \& de la Fuente, D. (2002). A decision support system for applying failure mode and effects analysis. International Journal of Quality \& Reliability Management, 19(2), 137-150. http://dx.doi.org/10.1108/02656710210413480.

Recchia, W. M. (2016). Aplicação da metodologia FMEA na gestão de risco no planejamento estratégico da UFSCar (Master's thesis). Universidade Federal de São Carlos, São Carlos.

Rogers, D. S., \& Tibben-Lembke, R. S. (1999). Going backwards: reverse logistics trends and practices. Reno: University of Nevada.

Schein, E. H. (1992). Organization culture and leadership: a dynamic view. San Francisco: Jossey Bass.

Sheremetieff, A., Jr. (2015). Modelo de otimização da expansão de capacidade de cadeias de suprimento globais (Doctorate's dissertation). COPPE, Universidade Federal do Rio de Janeiro, Rio de Janeiro.

Silva, N., \& Zanelli, J. C. (2004). Psicologia, organizações e trabalho no Brasil: cultura organizacional (pp. 407-442). Porto Alegre: Artmed. 
Silva, R. L. A., Soares, P. R. F. T., \& Silva, A. K. B. (2008). Análise de risco utilizando a ferramenta FMEA em um gerador de vapor. In Anais do XXVIII Encontro Nacional de Engenharia de Produção (ENEGEP). Rio de Janeiro: ABEPRO.

Silva, R. O. (2002). Teorias da administração. Sao Paulo: Pioneira Thompson Learning.

Sinnecker, C. O. (2007). Estudo sobre a importância da logística reversa em quatro grandes empresas da região metropolitana de Curitiba (Master's thesis). Production Engineering and Systems, Pontifícia Universidade Católica do Paraná, Curitiba.

Srivastava, S. K. (2008). Network design for reverse logistic. Omega: The International Journal of Management Science, 36(4), 535-548. http://dx.doi.org/10.1016/j.omega.2006.11.012.

Yin, R. K. (2001). Estudo de caso: planejamento e métodos (2. ed.) Porto Alegre: Bookman. 